\title{
Termik Santralin Çevresel Kirletici Etkisinin Toprak Kirlilik Yönetmelikleri Çerçevesinde Değerlendirilmesi
}

\section{Yakup Kenan KOCA}

Dicle Üniversitesi Ziraat Fakültesi Toprak Bilimi ve Bitki Besleme Bölümü, Diyarbakır https://orcid.org/0000-0001-9285-1416

৫:ykkoca@dicle.edu.tr
ÖZET
Tarım toprakları insan beslenmesinin ana kaynağını oluşturmaktadır. Ancak bu topraklar çeşitli etmenler tarafından kirletilmektedir. Bu kirliliğin temel sebeplerinden birisi de topraklarda kurşun, kadmiyum, krom, bakır, nikel ve çinko gibi ağır metallerin olması gereken düzeyin üzerinde bulunmasıdır. Sözkonusu bu metaller ana materyal olarak kaynaklı olabileceği gibi antropojenik etkilerle de toprakta bulunma düzeyi artabilmektedir. Toprakta yüksek düzeyde bulunması olumsuz etkilere sebep olurken, ağır metallerin aynı zamanda topraktan uzaklaştırılması da oldukça zordur. Toprakların kirliliğinin belirlenmesi ve kirliliğin önlenmesine yönelik çeşitli dönemlerde yasalar uygulamaya konulmuştur. Halen Türkiye'de kullanılmakta olan 2872 sayılı Çevre Kanunu ve bu kanun çerçevesinde uygulama yönetmelikleri bulunmaktadır. Sözkonusu yasa çerçevesinde 2005 yılında Toprak Kirliliği ve Kontrolü Yönetmeliği yayınlanmıştır. Bu yönetmelik kimi hataları barındırsa da çeşitli çalışmalarda kullanılmıştır. 2010 yılında yayımlanan Toprak Kirliliğinin Kontrolü ve Noktasal Kaynaklı Kirlenmiş Sahalara Dair Yönetmelik ile 2005 yılı yönetmelik kaldırılmış ve toprak kirliliğinin belirlenmesinde yeni bir değerlendirme uygulamaya konulmuştur. Bu çalışmada Şırnak İli Silopi ilçesinde bulunan termik santral ve etrafinda bulunan tarım arazileri özelinde sözkonusu iki yönetmelik karşılaştırmalı olarak değerlendirilmeye çalışılmıştır.

\section{Araştırma Makalesi}

$\begin{array}{ll}\text { Makale Tarihçesi } \\ \text { Geliş Tarihi } & : 28.02 .2019 \\ \text { Kabul Tarihi } & : 27.06 .2019\end{array}$

\section{Anahtar Kelimeler}

Ağır metal

Toprak

Kirlilik

Çevre kanunu

Yönetmelikler

\section{Evaluation of Environmental Pollutant Effect of Thermal Power Plant in Soil Pollution Regulations}

\begin{abstract}
Agricultural land is the main source of human nutrition. However, these soils are contaminated by various factors. One of the main reasons for this pollution is the presence of heavy metals such as lead, cadmium, chromium, copper, nickel and zinc in the soils. These heavy metals, which have more negative effects than other soil pollutants, are also difficult to remove from the soil. Laws were applied in various periods for the determination of pollution of the soils and prevention of pollution. Environmental Law No. 2872 is still in use in Turkey and there are the implementing regulations under the law. The Regulation on Soil Pollution and Control was published in 2005. Although this regulation contains some errors, it has been used in various studies. With the Regulation on Soil Pollution Control and Point Source Contaminated Sites published in 2010, the regulation was abrogated in 2005 and a new assessment was implemented for determination of soil pollution. In this study, two regulations regarding the fossil fuel plant and the surrounding agricultural lands in the Silopi district of Şırnak were evaluated.
\end{abstract}

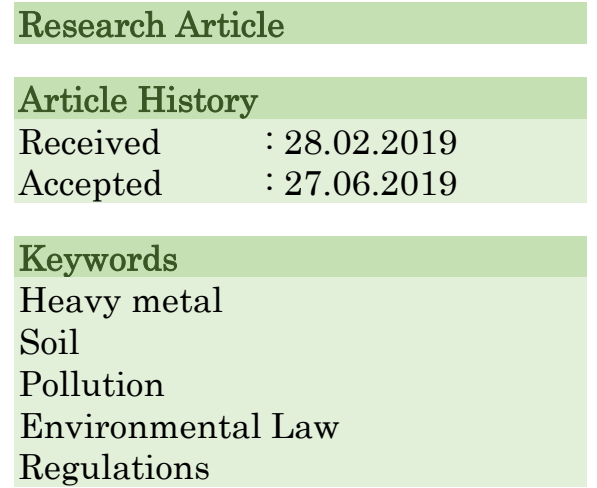

\begin{tabular}{c} 
To Cite : Koca YK 2019. Termik Santralin Çevresel Kirletici Etkisinin Toprak Kirlilik Yönetmelikleri Çerçevesinde \\
Değerlendirilmesi. KSÜ Tarım ve Doğa Derg. 22(Ek Sayı 1): 148-153. DOI: 10.18016/ksutarimdoga.vi.533995 \\
\hline
\end{tabular}

\section{GİRIŞ}

Artan nüfusun en önemli ihtiyaçları arasında görülmekte olan barınma ve beslenme kimi zaman birbiri ile çakışmaktadır. Artan nüfusun barınma 
ihtiyacı için yapılan binaların bir kısmı tarım arazileri üzerine kurulmaktadır. Mevcut yerleşim yerlerinden daha uzakta tarımsal potansiyeli düşük araziler bulunmakta iken çeşitli sebeplerle yeni yerleşim yapıları bu alanlara kurulmayıp, mevcut yerleşimin hemen etrafinda bulunan arazilere yapılmaktadır. Kimi zaman tarımsal anlamda yüksek potansiyeli olan araziler, insan yapısı objelerle istila edilmekte ve bu araziler tarım dışına çıkarılmaktadır. Kimi zaman da bu yapıların çevreye yarattığı olumsuz etkiler de arazilerin mevcut potansiyelinin düşmesine neden olmaktadır. Yeryüzündeki en önemli doğal kaynaklardan biri olarak görülen toprakların erozyonla kaybı, endüstriyel, evsel ve tarımsal kökenli kirleticilerle kirlenmesi, amaç dışı kullanımı vb. şekillerde yok edilmesi nüfusun diğer temel ihtiyacı olan beslenme üzerine olumsuz etkide bulunmaktadır (Tok, 1997).

Halen yürürlükte olan 2872 sayılı çevre kanuna göre çevre, canlıların yaşamları boyunca ilişkilerini sürdürdükleri ve karşılıklı olarak etkileşim içinde bulundukları biyolojik, fiziksel, sosyal, ekonomik ve kültürel ortamı olarak tanımlanmaktadır. Söz konusu kanuna göre çevre kirliliği ise, çevrede meydana gelen ve canlıların sağlığını, çevresel değerleri ve ekolojik dengeyi bozabilecek her türlü olumsuz etki olarak tanımlanmaktadır (Anonim, 1983). Çevre ile ilgili çok fazla sayıda çalışma olmakla birlikte ele alınan en önemli konular içerisinde ise çevre kirliliği önemli bir yer tutmaktadır. Son yıllarda bu konuda yapılan çalışmaların önemli bir bölümü ise çevre kirliliği ve etkilerine yönelik olmuştur (Sönmez ve ark, 2008; Çağlaırmak ve Hepçimen, 2010;.Karaca ve Turgay, 2012; Menteşe, 2017). Ekosistemin en önemli bileşenlerinden biri olan toprak ise bu kirlenmelerden önemli düzeyde etkilenmektedir.

Toprak kirliliği, Karaca ve Turgay (2012) tarafindan genel bir tanımla insan etkileri (yanlış tarım tekniklerinin uygulanması, yanlış ve fazla gübre ile tarımsal mücadele ilaçlarının kullanımı, atık ve artıkları, zehirli ve tehlikeli maddelerin toprakta birikmesi) sonucu toprağın fiziksel, kimyasal, biyolojik ve jeolojik yapısının bozulması şeklinde tanımlanmıştır. Başlıca çevre kirletici etmenler olarak erozyon, tarımsal kirleticiler, endüstriyel kirlenme, tarım alanlarının amaç dışı kullanımı, katı atıklar değerlendirilmektedir.

Fiziksel özellik açısından yoğunluğu $5 \mathrm{~g} / \mathrm{cm}^{3}$ ten daha yüksek olan metaller ağır metal olarak tanımlanmaktadır. $\mathrm{Bu}$ grubun içine kurşun, kadmiyum, krom, demir, kobalt, bakır, nikel, civa ve çinko olmak üzere 60'tan fazla metal girmektedir (Kahvecioğlu ve ark., 2009; Okcu ve ark., 2009). Ağır metallerin toprakta birikimi ve bitki tarafindan alınması ile bitki doku ve organlarında vejetatif ve generatif gelişimi olumsuz olarak etkilemektedir (Sarı, 2009). Ağır metaller bu toksik etkileri nedeniyle bitkilerde transpirasyon, stoma hareketleri, su absorbsiyonu, fotosentez, enzim aktivitesi, çimlenme, protein sentezi, membran stabilitesi, hormonal denge gibi birçok fizyolojik olayın bozulmasına neden olmaktadırlar (Asri ve Sönmez, 2006; Sarı, 2009).

Toprak kirlilik etmenlerinden biri olarak görülen ağır metal kirliliği ve buna ilişkin yönetmelikler bu çalışmanın temelini oluşturmaktadır. Özellikle ağır metal ile kirlenmiş olan arazilerin bir kısmı geri döndürülemez nitelikte kirlenmeye maruz kalması durumunda araziler tamamen tarım dışına da çıkabilmektedir. $\mathrm{Bu}$ arazilerden alınan toprak örneklerinin yapılan analizleri sonucu yönetmeliklerde belirlenen sınır değerlerinin içinde kalması ya da bu sınır değerlerinin üzerinde olması ile kirlilik tanımlaması yapılmaktadır. Bu çalışmada Şırnak İli Silopi ilçesinde bulunan termik santralin çevreye olan etkisinin yönetmelikler çerçevesinde değerlendirilmesi ele alınmıştır.

\section{MATERYAL ve METOD}

Çalışmada kirletici kaynak olarak değerlendirilen termik santral Şırnak İli Silopi ilçe merkezinin yaklaşık 4,5- $5 \mathrm{~km}$ batısında Cizre-Silopi karayolunun hemen yanında yer almaktadır (Şekil 1).

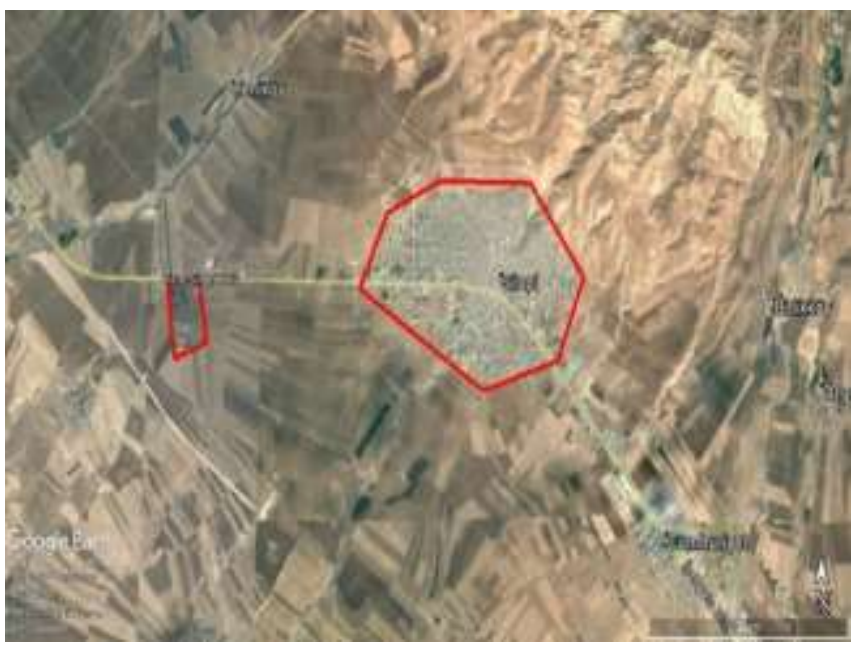

Şekil 1. Çalışma alanı örnekleme alanları

Örnekleme yapılan parseller ise termik santral ile Silopi ilçe merkezi arasında kalan ve tamamında buğday yetiştirilen arazilerdir. Bölgede hakim rüzgar yönünün kuzey olmasindan dolayı, örnekleme yapmaya en uygun araziler Cizre-Silopi karayolunun güney kısmında kalan araziler olarak belirlenmiştir. Örnekleme yapılan parsellerin koordinatları Çizelge 1 'de verilmiştir. Parsellerin büyüklüğüne bağlı olarak araziyi temsil edecek şekilde 25-30 noktadan yüzey toprak $(0-30 \mathrm{~cm})$ örneklemesi yapılmış ve her parsele ait 1 adet toprak örneği paçal haline getirilerek toprak örneklemesi yapılmıştır. Santral çevresindeki arazilerin yanı sıra, yeni yönetmeliğe göre, santralden yaklaşı $3,5-4 \mathrm{~km}$ uzaklıkta aynı ana materyal 
üzerinde bulunan ve referans olarak tanımlanan alandan da bir adet toprak örneklemesi yapılmıştır. Şahit olarak alınan bu alanda da aynı tarımsal üretim (buğday) yapılmaktadır. Laboratuvara götürülen topraklar uygun şartlarda kuru hava ortamına bırakılmıştır. Bu aşamada her parselden alınan örnek poşeti açılmış; uygun kurutma kâğıtlarının üzerine serilmiştir. Öğütülen topraklar $2 \mathrm{~mm}$ açıklıklı elek ile elenmiş ve analize hazır hale getirilmiştir.

Toprak örneklerinde Bakır $(\mathrm{Cu})$, Çinko (Zn), Demir (Fe), Krom (Cr), Nikel (Ni), Kadmiyum (Cd) ve Kurşun $(\mathrm{Pb})$ analizleri yapılmıştır. Toplam ağır metal analizleri TÜBİTAK-MAM Çevre ve Temiz Üretim Enstitüsü laboratuvarlarında EPA 6020 A metodu ICP-MS ile yapılmış ve analiz sonucu elde edilen değerler toprak kirliliği yönetmelikleri çerçevesinde değerlendirilmiştir. Bu kapsamda mülga 2005 yılında yayımlanan yönetmelik ile halen yürürlükte olan 2010 yılında yayımlanan yönetmelikler çerçevesinde arazi topraklarındaki ağır metal kirliliği durumu değerlendirilmiştir.
Çizelge 1. Örnekleme yapılan noktaların koordinatları

\begin{tabular}{|l|l|l|}
\hline Örnekleme Noktası & \multicolumn{2}{|c|}{ Koordinatları } \\
\hline 1 nolu örnekleme noktası & $37^{\circ} 14^{\prime} 17^{\prime \prime} \mathrm{K}$, & $37^{\circ} 14^{\prime} 07^{\prime \prime} \mathrm{K}$, \\
& $42^{\circ} 24^{\prime} 54^{\prime \prime} \mathrm{D}$, & $42^{\circ} 25^{\prime} 04^{\prime \prime} \mathrm{D}$, \\
\hline 2 nolu örnekleme noktası & $37^{\circ} 14^{\prime} 16^{\prime \prime} \mathrm{K}$, & $37^{\circ} 13^{\prime} 50^{\prime \prime} \mathrm{K}$, \\
& $42^{\circ} 25^{\prime} 21^{\prime \prime} \mathrm{D}$, & $42^{\circ} 26^{\prime} 41^{\prime \prime} \mathrm{D}$, \\
\hline \multirow{2}{*}{ 3 nolu örnekleme noktası } & $37^{\circ} 14^{\prime} 02^{\prime \prime} \mathrm{K}$, & $37^{\circ} 13^{\prime} 41^{\prime \prime} \mathrm{K}$, \\
& $42^{\circ} 25^{\prime} 21^{\prime \prime} \mathrm{D}$, & $42^{\circ} 26^{\prime} 00^{\prime \prime} \mathrm{D}$, \\
\hline \multirow{2}{*}{ 4 nolu örnekleme noktası } & $37^{\circ} 14^{\prime} 09^{\prime \prime} \mathrm{K}$, & $37^{\circ} 13^{\prime} 48^{\prime \prime} \mathrm{K}$, \\
& $42^{\circ} 25^{\prime} 20^{\prime \prime} \mathrm{D}$, & $42^{\circ} 26^{\prime} 04^{\prime \prime} \mathrm{D}$, \\
\hline 5 nolu örnekleme noktası & $37^{\circ} 13^{\prime} 44^{\prime \prime} \mathrm{K}$, & $37^{\circ} 13^{\prime} 30^{\prime \prime} \mathrm{K}$, \\
& $42^{\circ} 26^{\prime} 03^{\prime \prime} \mathrm{D}$, & $42^{\circ} 26^{\prime} 31^{\prime \prime} \mathrm{D}$, \\
\hline
\end{tabular}

Toprak Kirliliğinin Kontrolü Yönetmeliği (Anonim, 2005) toprak kirliliğine yönelik tüm çalışmalarda referans olarak alınmıştır. Sözkonusu yönetmeliğin Ek-1'inde toprakta ağır metal sınır değerleri verilmiştir (Çizelge 2). Verilen bu sınır değerleri toprak pH'sına göre değişmekle birlikte bu sınır değerlerinin üzerindeki ölçülen değerlerde topraklarda kirlilik olduğu değerlendirilmektedir.

Çizelge 2. 2005 yılı yönetmeliğinde ağır metal sınır değerleri

\begin{tabular}{|c|c|c|c|}
\hline Ağır Metal (Toplam) & $\begin{array}{c}\text { PH 5- } 6 \\
\text { mg/kg Firın Kuru Toprak }\end{array}$ & & $\begin{array}{c}\mathrm{pH}>6 \\
\mathrm{mg} / \mathrm{kg} \text { Firın Kuru Toprak }\end{array}$ \\
\hline Kurşun & 50 & $* *$ & $300 * *$ \\
\hline Kadmiyum & 1 & $* *$ & $3 * *$ \\
\hline Krom & 100 & ** & $100 * *$ \\
\hline Bakır* & 50 & $* *$ & $140^{* *}$ \\
\hline Nikel $^{*}$ & 30 & ** & $75^{* *}$ \\
\hline Çinko * & 150 & $* *$ & $300 * *$ \\
\hline
\end{tabular}

${ }^{*} \mathrm{pH}$ değeri 7'den büyük ise çevre ve insan sağlığına özellikle yer altı suyuna zararlı olmadığı durumlarda Bakanlık sınır değerleri \%50’ye kadar artırabilir.

** Yem bitkileri yetiştirilen alanlarda çevre ve insan sağlığına zararlı olmadığı bilimsel çalışmalarla kanıtlandığı durumlarda, bu sınır değerlerin aşılmasına izin verilebilir.

Ancak Toprak Kirliliğinin Kontrolü ve Noktasal Kaynaklı Kirlenmiş Sahalara Dair Yönetmeliğin (Anonim, 2010) 40. Maddesinde "31/5/2005 tarihli ve 25831 sayılı Resmî Gazete'de yayımlanan Toprak Kirliliğinin Kontrolü Yönetmeliği yürürlükten kaldırılmıştır." denilmektedir. Sözkonusu yeni yönetmeliğin amacı alıcı ortam olarak toprağın kirlenmesinin önlenmesi, kirlenmenin mevcut olduğu veya olması muhtemel sahaları ve sektörleri tespit etmek, kirlenmiş toprakların ve sahaların temizlenmesi ve izlenmesi esaslarını sürdürülebilir kalkınma hedefleriyle uyumlu bir şekilde belirlemektir olarak tanımlanmıştır.

Toprak Kirliliğinin Kontrolü ve Noktasal Kaynaklı Kirlenmiş Sahalara Dair Yönetmeliğin Ek-9'unda "Birinci Aşama Değerlendirmede saha denetimi esnasında sahanın kirlilik durumu konusunda kesin bir karara varılamadığı ya da kirlendiğinden şüphe duyulduğu takdirde, şüpheli sahada herhangi bir noktasal kaynak veya insan faaliyeti nedeniyle kirlenmiş olduğu düşünülen/varsayılan alandan alınan örneklerde ölçümleri yapılır. Bu ölçümler "ölçüm değeri (ÖD)" olarak adlandırılır; bu değerlerden en yüksek olanı da maksimum ölçüm değeri, ÖDmaks, olarak adlandırılır. ODmax sahaya özgü "referans değeri (RD)" ile karşılaştırılır." denilmektedir.

Yapılan hesaplamada "Sahada ölçülen değer(ler)in, referans değer(ler) ile karşılaştırılması yapılmakta ve referans değerden sapma düzeyine bakılmaktadır. Sapma düzeyi, sahanın, herhangi bir noktasal kaynaklı faaliyet nedeniyle etkilenip etkilenmediğini belirlemede ve dolayısıyla, izlenecek yolu işaret etmekte kullanılmaktadır. Değerlendirme Çizelge 3’te belirtilen temel çerçeveye göre yapılmaktadır. Buna göre, eğer maksimum ölçülen değerin referans değere oranı 1 veya 1'den küçükse; sahanın Takip Gerektirmeyen saha olduğu kararına varılmaktadır. Eğer sapma değeri 1 ile 25 değerleri arasında ise; saha İkinci Aşama Değerlendirmeye tabi Takip Gerektiren 
Saha olduğu kararına varılmaktadır. Sapma değeri 25 ’ten büyükse, kirliliğin fazla ve tehlikeli olduğuna kanaat getirilmekte ve sahanın Bakanlıkça belirlenen süreç uyarınca temizlenmesi gereken Kirlenmiş Saha olduğuna karar verilmektedir.

Çizelge 3. Yönetmelikte belirtilen kirlilik değerlendirilmesi

\begin{tabular}{|cl|}
\hline $\begin{array}{c}\text { KRİTER } \\
\text { (Sapma }=\begin{array}{c}\text { Oçülen Değer/Referans } \\
\text { Değer) }\end{array}\end{array}$ & Değerlendirme \\
\hline$\leq 1$ & Takip Gerektirmeyen Saha \\
\hline$>1$ & Ikinci Aşama Değerlendirme sürecine tabi Takip Gerektiren Saha \\
\hline$>25$ & $\begin{array}{l}\text { Bakanlıkça belirlenen süreç uyarınca temizlenmesi gereken Kirlenmiş } \\
\text { Saha }\end{array}$ \\
\hline
\end{tabular}

\section{BULGULAR}

Santral çevresinde bulunan 5 farklı parselden yapılan örneklemeler sonucunda arazilerin EPA 6020 A metodu ICP-MS ile belirlenen $\mathrm{Cu}, \mathrm{Zn}, \mathrm{Fe}, \mathrm{Cr}, \mathrm{Ni}$, Cd ve $\mathrm{Pb}$ analiz sonuçları Tablo 4'de verilmektedir. $\mathrm{Bu}$ değerlere göre kontrol parseli hariç arazilerin $\mathrm{Cu}$ içerikleri 39.57 ile $44.35 \mathrm{mg} \mathrm{kg}^{-1}$ arasında, Zn içerikleri 87.2 ile $100.82 \mathrm{mg} \mathrm{kg}^{-1}$ arasında, Cr içerikleri 169.3 ile $178.6 \mathrm{mg} \mathrm{kg}^{-1}$ arasında, Ni içerikleri 180.6 ile $190.2 \mathrm{mg}$ $\mathrm{kg}^{-1}$ arasında, Cd içerikleri 0.44 ile $0.5 \mathrm{mg} \mathrm{kg}^{-1}$ arasında ve $\mathrm{Pb}$ içerikleri 16.86 ile $18.2 \mathrm{mg} \mathrm{kg} \mathrm{kg}^{-1}$ arasında değişstiği belirlenmiştir.

Çizelge 4. Toprak analiz sonuçları

\begin{tabular}{|lllllllc|}
\hline Ölçülen Parametre & $\begin{array}{c}\text { Kontr } \\
\text { ol }\end{array}$ & $\begin{array}{c}1 \text { nolu } \\
\text { parsel }\end{array}$ & $\begin{array}{c}2 \text { nolu } \\
\text { parsel }\end{array}$ & $\begin{array}{c}3 \text { nolu } \\
\text { parsel }\end{array}$ & $\begin{array}{c}4 \text { nolu } \\
\text { parsel }\end{array}$ & $\begin{array}{l}5 \text { nolu } \\
\text { parsel }\end{array}$ & $\begin{array}{r}\text { 2005 yıll yönetmelik sınır } \\
\text { değerleri }\end{array}$ \\
\hline Bakır $\left(\mathrm{mg} \mathrm{kg}^{-1}\right)$ & 37.90 & 44.35 & 39.76 & 41.01 & 43.20 & 39.57 & 140 \\
\hline Çinko $\left(\mathrm{mg} \mathrm{kg}^{-1}\right)$ & 84.90 & 100.82 & 90.78 & 91.80 & 93.90 & 87.20 & 300 \\
\hline Demir $\left(\mathrm{mg} \mathrm{kg}^{-1}\right)$ & 40822 & 49970 & 48667 & 49959 & 51109 & 48441 & - \\
\hline Krom $\left(\mathrm{mg} \mathrm{kg}^{-1}\right)$ & 155.5 & $\mathbf{1 7 8 . 6}$ & $\mathbf{1 6 9 . 3}$ & $\mathbf{1 7 3 . 8}$ & $\mathbf{1 7 7 . 6}$ & $\mathbf{1 7 5 . 9}$ & 100 \\
\hline Nikel $\left(\mathrm{mg} \mathrm{kg}^{-1}\right)$ & 155.8 & $\mathbf{1 8 7 . 2}$ & $\mathbf{1 8 0 . 6}$ & $\mathbf{1 8 5 . 1}$ & $\mathbf{1 9 0 . 2}$ & $\mathbf{1 8 3 . 3}$ & 75 \\
\hline Kadmiyum $\left(\mathrm{mg} \mathrm{kg}^{-1}\right)$ & 0.39 & 0.44 & 0.47 & 0.47 & 0.50 & 0.44 & 3 \\
\hline
\end{tabular}

$\mathrm{Bu}$ analiz sonuçlarına göre, arazilerde ağır metal kirliliğinin olup olmadığının belirlenmesi amacıyla topraklarda ağır metal kirlilik düzeyini belirleyen mülga yönetmelik ile mevcut yönetmelik değerleri ele alınmıştır. 2005 yılında yayımlanan mülga yönetmeliğe göre $\mathrm{pH}>6$ olduğu değerlendirildiğinde, arazinin ağır metallerce kirli olarak sayllabilmesi için Cu'nun 140 mg kg-1; Zn'nin 300 mg kg-1; Cr'nin 100 mg $\mathrm{kg}^{-1}$; Ni'nin 75 mg kg-1; Cd'nin 3 mg kg-1 ve Pb'nin 300 $\mathrm{mg} \mathrm{kg}{ }^{-1}$ üzerinde olması gerekmektedir. Sözkonusu yönetmelikte $\mathrm{Fe}$ bir kirletici olarak görülmemiştir. Daha sonradan yayımlanan ve halen yürürlükte olan yönetmeliğe göre ise, alanın kirlenmiş saha olarak kabul edilebilmesi için, kirlenmediği varsayılan alandan alınan örneklerden 25 kat daha fazla ağır metal yüküne sahip olması gerekmektedir. $\mathrm{Bu}$ yönetmelikler uyarınca kirletici olarak varsayılan termik santrale çeşitli mesafelerde bulunan 5 parselde kirlenme olup olmadığı aşağıda tartışılmış ve değerlendirilmiştir.

1 nolu parsel değerlendirmesi: Sözkonusu parsel termik santralin hemen sinırında bulunmaktadır. $\mathrm{Bu}$ parselden alınan toprak örneklerinde $\mathrm{Cu} 44.35 \mathrm{mg} \mathrm{kg}$ 1; Zn $100.82 \mathrm{mg} \mathrm{kg}^{-1}$; Fe 49970 mg kg-1; Cr 178.6 mg kg1; $\mathrm{Ni} 187.2 \mathrm{mg} \mathrm{kg}^{-1}$; $\mathrm{Cd} 0.44 \mathrm{mg} \mathrm{kg}^{-1}$ ve $\mathrm{Pb} 17.30 \mathrm{mg} \mathrm{kg}$ 1 olarak belirlenmiştir. Analiz sonuçları mülga yönetmeliğe göre değerlendirildiğinde $\mathrm{Cu}, \mathrm{Zn}, \mathrm{Fe}, \mathrm{Cd}$ ve $\mathrm{Pb}$ sınır değerleri içerisinde kalmakta iken $\mathrm{Cr}$ ve $\mathrm{Ni}$ sınır değerlerin üzerinde çıkmaktadır. Sözkonusu yönetmeliğe göre $\mathrm{Cr}$ maksimum sinır değerden \%78; $\mathrm{Ni}$ ise yaklaşık \%149 daha fazla bulunmaktadır. Ancak mevcut yönetmeliklere göre arazi toprakları değerlendirildiğinde ise, topraklar temizlenmesi gereken kirlenmiş saha olarak kabul edilmeyen alanlar içerisinde yer aldığı; ancak takip gerektiren sahalar içerisinde yer aldığı görülmektedir.

2 nolu parsel değerlendirmesi: 1 nolu parsele göre santrale biraz daha uzakta olan topraklarm analiz sonuçları topraklarda $\mathrm{Cu} 39.76 \mathrm{mg} \mathrm{kg}^{-1}$; Zn $90.78 \mathrm{mg}$ $\mathrm{kg}^{-1}$; Fe $48667 \mathrm{mg} \mathrm{kg}^{-1}$; Cr $169.3 \mathrm{mg} \mathrm{kg}^{-1}$; Ni $180.6 \mathrm{mg}$ $\mathrm{kg}^{-1}$; Cd $0.47 \mathrm{mg} \mathrm{kg}^{-1}$ ve $\mathrm{Pb} 17.06 \mathrm{mg} \mathrm{kg}^{-1}$ olduğunu göstermektedir. Bu verilere göre arazi topraklarında bulunan $\mathrm{Cr}$ ve $\mathrm{Ni}$ dışında diğer ağır metaller mülga yönetmeliğe göre sınır değerleri içerisinde kalmaktadır. Mülga yönetmeliğe göre $\mathrm{Cr}$ bulunması gereken üst sinırdan \%69; Ni ise maksimum değerden \%140 daha fazla bulunmaktadır. Mevcut yönetmeliğe göre arazi toprakları değerlendirildiğinde ise topraklar kirlenmiş saha olarak kabul edilmemekte; ancak takip gerektiren saha olarak değerlendirilmektedir.

3 nolu parsel değerlendirilmesi: 2 nolu parsele komşu olan 3 nolu parselin analiz sonuçlarına göre topraklarda $\mathrm{Cu} 41.01 \mathrm{mg} \mathrm{kg}^{-1} ; \mathrm{Zn} 91.80 \mathrm{mg} \mathrm{kg}^{-1} ; \mathrm{Fe}$ $49959 \mathrm{mg} \mathrm{kg}^{-1}$; Cr $173.8 \mathrm{mg} \mathrm{kg}^{-1}$; Ni $185.1 \mathrm{mg} \mathrm{kg}^{-1}$; Cd $0.47 \mathrm{mg} \mathrm{kg}^{-1}$ ve $\mathrm{Pb} 17.10 \mathrm{mg} \mathrm{kg}^{-1}$ düzeyindedir. Mülga yönetmeliğe göre topraklarda $\mathrm{Cr}$ ve $\mathrm{Ni}$ dışındaki diğer 
ağır metaller belirtilen sınırlar içerisinde kalmaktadır. Ancak Cr sınır değerden \%73; Ni ise sınır değerden \%147 daha yüksek bulunmaktadır. Mevcut yönetmeliklere göre aynı topraklar değerlendirildiğinde ise topraklarda kirlilik mevcut olmadığ1; ancak takip gerektiren saha olduğu değerlendirilmektedir.

4 nolu parsel değerlendirilmesi: Parselden alınan örneklerin analiz sonuçlarına göre topraklarda $\mathrm{Cu}$ $43.20 \mathrm{mg} \mathrm{kg}^{-1}$; Zn $93.90 \mathrm{mg} \mathrm{kg}^{-1}$; Fe $51109 \mathrm{mg} \mathrm{kg}^{-1}$; Cr $177.6 \mathrm{mg} \mathrm{kg}^{-1}$; Ni $190.2 \mathrm{mg} \mathrm{kg}^{-1}$; Cd $0.50 \mathrm{mg} \mathrm{kg}^{-1} \mathrm{ve} \mathrm{Pb}$ $18.20 \mathrm{mg} \mathrm{kg}^{-1}$ düzeyinde bulunmaktadır. Eski yönetmelik çerçevesinde değerlendirildiğinde parsel topraklarında $\mathrm{Cu}, \mathrm{Zn}, \mathrm{Fe}, \mathrm{Cd}$ ve $\mathrm{Pb}$ sinır değerler içerisinde yer almaktadır. Buna karşın $\mathrm{Cr}$ ve $\mathrm{Ni}$ ise bulunması gereken sınır değerlerinden sirasıyla \%78 ve \%153 daha fazla bulunmaktadır. Mevcut yönetmelikler çerçevesinde ise parsel toprakları takip gerektiren saha olarak değerlendirilmektedir.

5 nolu parsel değerlendirilmesi: Yapılan analiz sonuçlarına göre parsel topraklarında $\mathrm{Cu} 39.57 \mathrm{mg} \mathrm{kg}$ 1; Zn $87.20 \mathrm{mg} \mathrm{kg}^{-1}$; Fe $48441 \mathrm{mg} \mathrm{kg}^{-1}$; Cr $175.9 \mathrm{mg} \mathrm{kg}$ 1; Ni $183.3 \mathrm{mg} \mathrm{kg}^{-1}$; Cd $0.44 \mathrm{mg} \mathrm{kg}^{-1}$ ve $\mathrm{Pb} 16.86 \mathrm{mg} \mathrm{kg}$ 1 düzeyinde bulunmaktadır. Yürürlükten kaldırılan yönetmelik çerçevesinde parsel toprakları değerlendirildiğinde bulunması gereken maksimum düzeyden daha fazla olan $\mathrm{Cr}(\% 76)$ ve $\mathrm{Ni}$ (\%144) dışında diğer ağır metaller sınır değerleri içerisinde yer almaktadır. Mevcut yönetmeliğe göre parsel toprakları takip gerektiren saha kapsamında değerlendirilmektedir.

Tüm parsel topraklarında yapılan analiz sonuçları, mülga yönetmeliğe göre değerlendirildiğinde topraklarda $\mathrm{Cu}, \mathrm{Zn}, \mathrm{Cd}$ ve $\mathrm{Pb}$ değerlerinin sinır değerlerinin altında; $\mathrm{Cr}$ ve $\mathrm{Ni}$ değerlerinin ise sınır değerlerinin üzerinde olduğu görülmektedir. $\mathrm{Bu}$ arazilerde $\mathrm{Cr}$ en düşük $169.3 \mathrm{mg} \mathrm{kg}^{-1}$ ile 2 nolu parselde iken en yüksek $178.6 \mathrm{mg} \mathrm{kg}^{-1}$ ile 1 nolu parselde belirlenmiştir. Cr'ye benzer şekilde $\mathrm{Ni}$ ise en düşük $180.6 \mathrm{mg} \mathrm{kg}^{-1}$ ile 2 nolu parselde en yüksek $190.2 \mathrm{mg} \mathrm{kg}^{-1}$ ile 4 nolu parselde belirlenmiştir. Bu arazilerde mülga yönetmeliğe göre $\mathrm{Cr}$ ve Ni kirliliği söz konusu iken; mevcut yönetmeliğe göre kirlenmediği varsaylan alan ile arasinda 25 kat fark bulunmadığından dolayı söz konusu parseller İkinci Aşama Değerlendirme Sürecine Tabi Takip Gerektiren Saha olarak tanımlanmakta ancak kirlenmiş saha olarak tanımlanamamaktadır. Mevcut yönetmeliğe göre bu arazilerde ağır metal kaynaklı kirlilik bulunmamaktadır.

Mülga yönetmelikte bulunan değerler toprak pH'sina göre değişmekle birlikte net rakamlar içermekte idi. Ancak değerlendirmeye alınan bu sınır değerler, ana materyalin etkisini yok saymakta olduğu görülmüştür. Nitekim $\mathrm{Cr}$ ve Ni'nin ana materyalden kaynaklı olabileceğine yönelik çok sayıda da çalışma bulunmaktadır. Sarı (2009) tarafindan yapılan çalışmada, serpantin ana materyali üzerinde oluşan topraklarda $\mathrm{Cr}$ düzeyinin genellikle yüksek olduğu belirtilmiştir. Ni'de $\mathrm{Cr}$ gibi serpantinli topraklarda fazla miktarda bulunur (Hossner ve ark., 1998). Çalışma kapsamında alınan toprak örneklerinde olduğu gibi, kimi topraklarda yüksek düzeyde bulunan $\mathrm{Cr}$ ve $\mathrm{Ni}$ için bulunan bu değerler kirlilik değil zenginleşme olarak değerlendirilmelidir. Çünkü kirletici kaynak olarak görülen santralden oldukça uzak olan topraklarda bile $\mathrm{Cr}$ ve Ni değerleri yüksek çıkmaktadır. Ve bu değerler ile mülga yönetmeliğe göre kirli olarak varsayılan alanlarda esasen kirlilik değil ana materyal kaynaklı $\mathrm{Cr}$ zenginleşmesi söz konusudur. Mülga yönetmeliğin en önemli eksikliği de buradan gelmektedir. Mevcut yönetmeliğe göre ise tüm parsellerden alınan toprak örnekleri ile kirlenmediği varsayılan yol, yerleşim ve santrale uzak olan bir parselden alınan toprak örneği ile karşılaştırılmış ve yönetmeliğe göre topraklarda ağır metal kaynaklı kirlilik bulunmadığı belirlenmiştir.

\section{TARTIŞMA ve SONUÇ}

Ağır metal kirliliğinden kaynaklı toprak kirliliğine dair 2005 ve 2010 yıllarında yayımlanan yönetmeliklerin ele alındığı bu çalışmada, her iki yönetmelikte de eleştirilen taraflar olduğu görülmüştür. Mülga yönetmelik net sınır değerleri belirtmesine rağmen, ana materyalden kaynaklanan yüksek değerleri göz ardı etmekte idi. Özellikle serpantin gibi ana materyale sahip olan topraklarda $\mathrm{Cr}$ ve $\mathrm{Ni}$ değerleri yüksek çıkabilmektedir. Alınan örneklerde ölçülen değerlerin yüksek çıkması durumunda mülga yönetmelik kirlilik olduğunu belirtmekte idi. Ancak çalışma kapsamında alınan örneklerde olduğu gibi topraklarda ölçülen değerler ana materyal kaynaklı da olabilmektedir.

Mevcut Toprak Kirliliğinin Kontrolü ve Noktasal Kaynaklı Kirlenmiş Sahalara Dair Yönetmeliğin uygulanmasında çeşitli sakıncalar olduğu görülmüştür. Nitekim kirlenmediği varsayılan alan ile kirlendiği varsayılan alandan alman toprak örneklerinde yapılan analizlerin karşılaştırılması ile arazilerde kirlilik değerlendirilmektedir. Yürürlükte olan mevcut yönetmeliğe göre, her iki toprak arasındaki değerler 1 veya 1 'den küçükse "takip gerektirmeyen saha" olarak değerlendirilmektedir. Bu değer 1 ile 25 arasında ise "ikinci aşama değerlendirme sürecine takip gerektiren saha" olarak tanımlanmaktadır. Bu değerin ancak 25'in üzerinde olması durumunda ise "bakanlıkça belirlenen süreç uyarınca temizlenmesi gereken kirlenmiş saha" olarak tanımlanabilmektedir. Kirlendiği varsayılan arazideki ağır metal değerleri ancak ve ancak kirli olmadığ varsayılan alandaki değerlerin 25 kat veya daha fazla çıkması gerekir ki kirli olarak değerlendirilebilsin.

$\mathrm{Bu}$ yönetmeliğe göre, arazilerin çok önemli bir kısmı kirlenmiş saha olarak kabul edilemeyecektir. Çünkü 
mevcut yönetmelikteki bu oran kabul edilebilir bir oran olmaktan oldukça uzaktır. Kirlendiği varsayılan alandan alınan toprak örneğinde kimi ağır metallerin oranı yüksek çıksa bile bu yönetmeliğe göre kirlenmemiş alan olarak değerlendirilmek zorunda kalınmaktadır. 2005 yılında yürürlüğe giren ancak 2010 yılında yürürlükten kaldırılan yönetmeliğe göre, toprağın $\mathrm{pH}$ durumuna göre değişmekle birlikte belirli bir düzeyin üzerinde belirlenen ağır metaller topraktaki kirliliği ifade etmekte idi ve bu değerler oldukça net idi. Ancak değiştirilen yönetmelik ile arazilerdeki kirlilik durumu genellikle ikinci aşama değerlendirme sürecine tabi takip gerektiren saha olarak değerlendirilmekte ve kirli olmadığı ifade edilmektedir. Nitekim çalışma kapsamında ele alınan arazilerde olduğu gibi, toprak örneklemelerinde bazı ağır metaller yüksek çıkmış olmasına rağmen, mülga yönetmeliğe göre ağır metal bakımından kirli; mevcut yönetmeliğe göre kirli değil olarak değerlendirilmektedir.

Sürdürülebilir tarım kapsamında en önemli materyallerden birisi de tarım arazileridir. $\mathrm{Bu}$ arazilerin optimum bir şekilde kullanımı gelecek nesillere daha kaliteli topraklar bırakmak açısından önemlidir. Bu sebepten ötürü tarım ve çevre ile ilgili hazırlanan yönetmeliklerde tarım yapılan arazilerin nasıl daha fazla korunabileceği ve gelecek nesillere nasıl kaliteli bir toprak bırakılabileceğinin yolları daha net bir şekilde ortaya konması gerekmektedir. Ancak mevcut toprak kirliliği kontrolüne yönelik yapılan ve halen yürürlükte olan yönetmelikte bu durum çevre kirletici etmenlerin lehine olacak şekilde düzenlenmiştir. Amacı alıcı ortam olarak toprağın kirlenmesinin önlenmesi olan mevcut yönetmeliğin tekrar gözden geçirilerek revize edilmesi ve bu değerlendirmelerin çevre ve toprakların lehine olacak şekilde belirlenmesi bu kapsamda atılacak en önemli adımdir.

KAYNAKLAR

Algan FT, Bilen S 2005. Toprak Kirlenmesi ve
Biyolojik Çevre. Ankara Üniv. Zir. Fak. Dergisi, 36(1): 83-88

Anonim 1983. 2872 sayılı Çevre Kanunu. 11.8.1983 gün ve 18132 sayll Resmi Gazete.

Anonim 2005. Toprak Kirliliğinin Kontrolü Yönetmeliği. 31/5/2005 tarihli ve 25831 sayılı Resmî Gazete.

Anonim 2010. Toprak Kirliliğinin Kontrolü ve Noktasal Kaynaklı Kirlenmiş Sahalara Dair Yönetmelik. 08/06/2010 tarih ve 27605 sayılı Resmi Gazete.

Asri F, Sönmez S 2006. Ağır Metal Toksisitesinin Bitki Metabolizması Üzerine Etkileri. Derim, Batı Akdeniz Tarımsal Enstitüsü Dergisi, 23(2): 36-45.

Çağlaurmak N, Hepçimen, AZ 2010. Ağır Metal Toprak Kirliliğinin Gıda Zinciri ve İnsan Sağlığına Etkisi. Akademik Gıda, 8(2): 31-35

Hossner LR, Loppert RH, Newton RJ 1998. Literature review: Phytoaccumulation of chrmium. Uranium and plutonium in plant systems. Amarillo National resource Center for Plutonium. ANRCP-1998-3.

Kahvecioğlu Ö, Kartal G, Güven A, Timur S 2009. Metallerin çevresel etkileri-I. Metalurji Dergisi, 136: 47-53.

Karaca A, Turgay OC 2012. Toprak Kirliliği. Toprak Bilimi ve Bitki Besleme Dergisi, 1(1): 13-19.

Menteşe, S 2017. Çevresel Sürdürülebilirlik Açısından Toprak, Su ve Hava Kirliliği: Teorik Bir İnceleme. Uluslararası Sosyal Araştırmalar Dergisi, 10(53): 381-389.

Okcu M, Tozlu E, Kumlay AM, Pehluvan M 2009. Ağır Metallerin Bitkiler Üzerine Etkileri. Alınteri Dergisi, 17(B): 14-26.

Sarı T 2009. Edirne ve Çevresinde Otoban Kenarlarındaki Topraklarda Bazı Ağır Metal Kirliliğinin Araştırılması. Namı Kemal Üniversitesi, Fen Bilimleri Enstitüsü, Toprak AD, Yüksek Lisans Tezi, $53 \mathrm{~s}$.

Sönmez İ, Kaplan M, Sönmez, S 2008. Kimyasal Gübrelerin Çevre Kirliliği Üzerine Etkileri ve Çözüm Önerileri. Derim Dergisi, 25(2): 24-34 